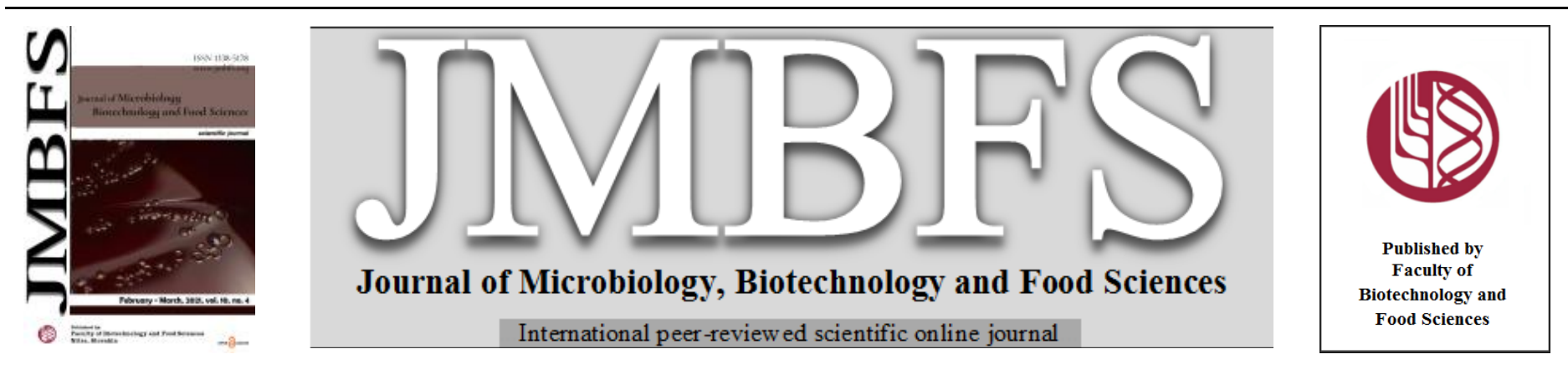

\title{
PHILIPPINE ETHNOBOTANICALS DOWNREGULATE lasR EXPRESSION LINKED TO QUORUM SENSING- MEDIATED BIOFILM FORMATION IN Pseudomonas aeruginosa
}

\author{
Rebecca I. Santos ${ }^{1}$, Wilson R. Jacinto ${ }^{2}$ and Khristina G. Judan Cruz ${ }^{1 *}$ \\ Address(es): Khristina G. Judan Cruz \\ ${ }^{1}$ Central Luzon State University, Department of Biological Sciences, 3120 Science City of Munoz, Nueva Ecija, Philippines. \\ ${ }^{2}$ De La Salle University -Dasmarinas, Biological Sciences Department, 4114 City of Dasmarinas, Cavite, Philippines.
}

*Corresponding author: kjcruz@clsu.edu.ph

doi: $10.15414 / j m b f s .2021 .10 .4 .592-597$

\section{ARTICLE INFO}

Received 4. 9. 2019

Revised 14. 10. 2020

Accepted 15. 10. 2020

Published 1. 2. 2021

Regular article

OPEN OACCESS

\begin{abstract}
The prevalence of antibacterial resistance has brought about a growing surge to develop novel approaches to control infectious diseases. Targeting Quorum-sensing (QS) - controlled virulence factors in bacteria has indicated a promising strategy for antipathogenic drugs. Extracts of Philippine Ilongot-Egongot ethnobotanicals Stachytarpeta jamaicensis, Adenanthera intermedia, Mikania micrantha, Hyptis suaveolens, Premna odorata, Cymbopogan winterianus, Phyllanthus urinaria, Dillenia philippinensis, Hydrocotyle vulgaris, Senna alata, Urena lobata, Ceiba pentandra, Ficus sp., Eleusine indica, Diplazium esculentum and Talahib (no known scientific name) were screened using microtiter plate biofilm formation assay for their QS inhibition activity against biofilm formation in Pseudomonas aeruginosa clinical isolate and Pseudomonas aeruginosa PNCM 1335.

Extracts of M. micrantha, H. suaveolens flowers, H. vulgaris, A. intermedia, E. indica leaves, D. esculentum and Talahib have inhibitory effect on $P$. aeruginosa clinical isolate biofilm formation. Decrease in biofilm formation was shown in extracts of $S$. jamaicensis., $M$. micrantha, $H$. suaveolens, $H$. vulgaris, $U$. lobata, C. pentandra, A. intermedia, E. indica, D. esculentum and Talahib. against $P$. aeruginosa PNCM 1335. RNA extracts of M. micrantha, Talahib and A. intermedia exhibited downregulation of lasR in both test bacteria using qRT-PCR analysis through absolute quantification. The prospects of these ethnobotanicals to inhibit bacterial virulence avoiding antibiotic resistance is presented in this paper.
\end{abstract}

Keywords: quorum sensing, biofilm, Pseudomonas aeruginosa, ethnobotanicals, las $R$

\section{INTRODUCTION}

The continuous emergence of pathogenic diseases has brought about indiscriminate use of antibiotics. This practice resulted to the development of antibiotic resistance and is now a global threat to public health (Kalia et al., 2007). With the prevalent progression of antibiotic-resistance in bacteria, interest for novel approaches to limit infectious diseases is greatly increasing.

Pseudomonas aeruginosa is a multi-drug resistant (MDR) human pathogen and known for their biofilm growth making it difficult to eliminate (Driscoll et al., 2007). Biofilm formation provides great advantage to $P$. aeruginosa where it can degrade host tissues with proteases and toxins, while being spared from antibiotic attack (Adonizio et al., 2008). Its flagellar motility as well as type IV pilimediated twitching motility has been shown to be essential for surface attachment and colony formation in biofilms. More importantly, however, is the fact that cell-to-cell communication, or quorum-sensing (QS), is critically involved in biofilm formation, particularly in the development of its typical threedimensional architecture (Antunes et al., 2010). A number of its genes and proteins are under QS regulation, suggesting that regulation of gene expression in populations is material to its successful pathogenesis in plant and animal hosts (Bauer \& Mathesius, 2004).

Hence, an approach referred to as the anti-pathogenic drug principle (Hentzer $e t$ al., 2003) restricts this QS-controlled virulence and pathogenesis in bacteria in the hope that invading bacteria will fail to synchronize its activities, and prevent establishment in the host (Rasmussen \& Givskov, 2006). Disabling quorumsensing systems in bacteria has become the new focal point in developing strategies to intercept bacterial pathogenicity (O'Loughlin et al., 2013).

Current search for new antimicrobials and anti-virulence agents is focused on natural products, specifically, plant-derived compounds. To this day, these compounds have provided the platform for developing new sets of antipathogenic drugs. The Philippines, aside from having an immense plant diversity, hosts a number of diverse ethnic communities that have depended mostly on plants and other natural products to treat diseases (Sia et al., 2002). Among these are the plants utilized by the members of the ethnic community of Ilongot-Egongots of Maria Aurora in the province of Aurora, Philippines. A recent survey of their traditional medicine revealed a varied and huge selection of ethnobotanicals for the treatment of many diseases and ailments (Balberona et al., 2018). Their novelty has attracted researches seeking for agents that may possess quorum sensing inhibiting (QSI) compounds, and provide additional validation of the traditional medicines (Adonizio et al., 2006). Phytochemicals mimic signals in bacteria and hence, may confuse their quorum sensing regulation (Bauer \& Mathesius, 2004).

The potential of anti-QS compounds has paved for systematic evaluation for these agents (Adonizio, 2008). While there are worldwide ethnobotanical explorations, Philippine ethnobotanical screenings on pharmacological activities are still quite limited. This paper presents the QSI activity of Philippine IlongotEgongot ethnobotanicals against a QS-controlled virulence factor, biofilm formation, in the bioreporter bacterial strain Pseudomonas aeruginosa up to the molecular level through the quantification of the expression of lasR, a QS-linked gene responsible for many virulence factors including biofilm formation.

\section{MATERIALS AND METHODS}

\section{Plant Sample Collection and Ethanol Extraction}

Through the permission of the tribal chieftains of the Ilongot-Eg'ongot community of Maria Aurora, Aurora, Philippines, plant samples were handpicked then placed in clean, properly labeled sacks, sealed and then transported to the laboratory for processing. The plants tested were: Stachytarpeta jamaicensis (Luzviminda) (leaves), Adenanthera intermedia (Kares) (leaves and seeds), Mikania micrantha (Ola-ola) (leaves), Hyptis suaveolens (Ambabangot) (flowers and leaves), Premna odorata (Asédaong) (leaves) , Cymbopogan winterianus (Taday) (leaves), Phyllanthus urinaria (Taltalikod) (leaves), Dillenia philippinensis (Katmon) (leaves), Hydrocotyle vulgaris (Gotu kola) (leaves), Senna alata (Bensola) (leaves), Urena lobata (Pukot) (leaves), Ceiba pentandra (Béték) (leaves), Ficus sp.(Balete) (leaves), Eleusine indica (Pag) (roots and leaves), Diplazium esculentum (Pako-pako) (leaves) and Talahib (whole plant) (no known scientific name). 
The protocols of Tan et al., (2013) and Srisawat (2007) as followed by Velasco et al., (2020) were used for ethanol extraction with modifications. The plant samples were cleaned using distilled water and $70 \%(\mathrm{v} / \mathrm{v})$ ethanol then air-dried. Fifty (50) grams of each ground plant sample was soaked in $500 \mathrm{ml}$ of $80 \%$ ethanol for 72 hours. This was filtered and the solvent removed using a rotary evaporator. The resulting extracts were stored in sterile bottles at temperatures between $0-5^{\circ} \mathrm{C}$. Sterilization of the The extracts was done through centrifugation at $10,000 \mathrm{x}$ g for 30 minutes, then membrane filtration (Acrodisc $25 \mathrm{~mm}$ Syringe Filter) with a pore diameter of $0.45 \mu \mathrm{m}$ pore size. The sterile extracts were stored at $2-8^{\circ} \mathrm{C}$. The sterility of the extracts was monitored by inoculating $100 \mu \mathrm{l}$ in brain heart infusion agar (BHIA).

\section{Preparation for Bacterial Culture}

Brain-heart infusion broth (BHIB) and agar (BHIA) were used to revive and maintain cultures of $P$. aeruginosa. Maintenance in special culture media was done as necessary. A reference strain, $P$. aeruginosa PNCM 1335 and a clinical isolate obtained from the University Medical Center, De La Salle Health Sciences Institute, Dasmariñas, Cavite, Philippines were used as test bacteria.

\section{Antibacterial Assay of Plant Extracts Against P. aeruginosa}

The protocol of Rezai et al. (2011) was used with some modifications. Colonies of $P$. aeruginosa from each strain cultured for 16-18 hours in BHIA were transferred to sterile distilled water, the turbidity was adjusted to McFarland 0.5 standard ( 1.5 x $108 \mathrm{CFU} / \mathrm{mL})$. Mueller Hinton Agar (MHA) plates were inoculated and streaked in three different directions over the surface of the agar to ensure the even distribution. On empty, sterile petri plates, $20 \mu \mathrm{l}$ of each extract was pipetted onto 6-mm sterile blank antibiotic discs and was allowed to stand for a few minutes to eliminate excess liquids. Using sterile forceps, infused discs were then transferred carefully and equidistant to each other onto $15-\mathrm{mm}$ MHA previously inoculated with $P$. aeruginosa. Norfloxacin and sterile distilled water served as positive and negative control; Triplicate plates were prepared for all of the treatments. After 24 to $48 \mathrm{hrs}$ period of incubation, the antibacterial activity of the plant extracts was noted for the appearance of zone of inhibition. Plant extracts should not exhibit zone of inhibition which was required for accuracy of the subsequent assay to rule out antibacterial-mediated decrease in virulence factor production (Fernando and Judan Cruz, 2020; Velasco et al., 2020)

\section{Microtitre Plate Biofilm Formation Assay}

The effect of plant extracts on the attachment phase of biofilm formation was measured by using a microtitre plate assay. $180 \mu \mathrm{l}$ of overnight cultures of $P$ aeruginosa were transferred to wells in the plates added with $20 \mu \mathrm{l}$ of each plant extract. This was incubated at $30^{\circ} \mathrm{C}$ for 40 hours without shaking. To remove planktonic cells, the plates were rinsed with sterile distilled water and air dried for 45 minutes. For staining, $150 \mu \mathrm{l}$ of $1 \%$ crystal violet solution in water for 45 minutes was used (Fernando and Judan Cruz, 2020; Velasco et al., 2020).

For quantification of biofilm, $200 \mu \mathrm{l}$ of $95 \%$ ethanol was added to destain the wells. $100 \mu \mathrm{l}$ from each well was then transferred to a new microtiter plate and the OD level was measured at $595 \mathrm{~nm}$ (Djordjevic et al., 2002). Presence and/o absence of growth inhibition was noted in biofilms and was then quantified using UV-visible Spectrophotometer (Biotek Instruments, Inc., USA) (Judan Cruz 2018; Velasco et al., 2020).

\section{lasR Gene Expression}

Four plant extracts that showed the lowest vallues in biofilm formation in the QSI Assay were chosen for the quantification of lasR expression.

\section{RNA Extraction}

RNA extraction was done using RNeasy Minikit (Qiagen, GmbH, Germany). For each sample, 25-50 mg acid-washed glass beads (150-600 $\mu \mathrm{m}$ diameter) were weighed in a $2 \mathrm{ml}$ safe-lock tubes. Bacteria were collected by centrifugation at $5000 \mathrm{x}$ g for five minutes at $4^{\circ} \mathrm{C}$. The supernatant was decanted and aspirated to ensure removal of remaining media. Buffer RLT was added $(350 \mu \mathrm{l}$ for $<5 \times 108$ and $700 \mu \mathrm{l}$ for $5 \times 108-1 \times 109$ number of bacteria). The suspension was transferred into the $2 \mathrm{ml}$ safe-lock tube containing the acid-washed beads. Cells were disrupted in the TissueLyser for five minutes at maximum speed. The suspension was centrifuged for 10 seconds at maximum speed. The supernatan was transferred into a new tube and the volume of the sample was determined. An equal volume of $70 \%$ ethanol was added and mixed by pipetting. Up to $700 \mu$ lysate was transferred to a spin column placed in a $2 \mathrm{ml}$ collection tube and was centrifuged for 15 seconds at $\geq 8000 \mathrm{x}$ g. Flow-through tube was discarded. 700 $\mu \mathrm{l}$ Buffer RW1 was added to the spin column. With lid closed gently, the spin column was centrifuged for 15 seconds at $\geq 8000 \mathrm{x}$ g to wash the spin column membrane. The spin column was placed in a new $2 \mathrm{ml}$ collection tube with the flow- through. Lids were closed gently and centrifuged at full speed for one minute. Spin column was then placed in a new $1.5 \mathrm{ml}$ collection tube. $30-50 \mu$ RNase-free water was added directly to the spin column membrane and was centrifuged for one minute at $\geq 8000 \mathrm{x}$ g to elute the RNA. This method followed the RNeasy Minikit protocol (Qiagen, GmbH, Germany)

\section{qRT-PCR Analysis through Absolute Quantification}

The expression of las $R$ in both the test bacteria was determined to evaluate QSI activity through qRT-PCR analysis. The specific primers were: lasR (F) 5 AAGTGGAAAATTGGAGTGGAG $3^{,}$and las $R$ (R) 5 GTAGTTGCCGACGACGATGAAG 3' (Sabharwal et al., 2014). An internal standard $16 S$ rRNA was used with the following primers: $16 S$ rRNA (F) 5' AGAGTRTGATCMTYGCTWAC $3^{\prime}$ and $16 \mathrm{~S}$ rRNA (R) 5' CGYTAMCTTWTTACGRCT 3' (Tripathi et. al., 2013). The qRT-PCR program is as follows: incubation at $42^{\circ} \mathrm{C}$ for $5 \mathrm{~min}$ for reverse transcription; 1 cycle at $95^{\circ} \mathrm{C}$ for $2 \mathrm{~min}$; then 45 cycles at $94^{\circ} \mathrm{C}$ for $20 \mathrm{~s}, 60^{\circ} \mathrm{C}$ for $20 \mathrm{~s}$ and $72^{\circ} \mathrm{C}$ for $50 \mathrm{~s}$ (Wada et al., 2009). KAPA One Step RT-PCR kit (KAPA Biosystems) was used for amplifications consisting of a mixture of 2.4 HPLC water, $5.0 \mu \mathrm{l}$ KAPA Universal Mix, $0.2 \mu \mathrm{l}$ dUTP, $0.5 \mu \mathrm{l}$ of reconstituted forward and reverse primers, $0.2 \mu \mathrm{l}$ RT Mix, and $1.0 \mu \mathrm{l}$ RNA template. Several concentrations of RNA with $16 \mathrm{~S}$ were used as internal control to quantify RNA transcript levels. Absolute quantification of the amplified transcripts was done through Bio-Rad CFX96TM Real-Time System Thermal Cycler, which plots a standard curve from where critical threshold $(\mathrm{Ct})$ values are derived. Through this, the concentration of its PCR signal $(\mathrm{Cq})$ is quantified into this standard curve (Illumina Inc., 2010).

\section{Statistical Analysis}

The non-parametric Mann-Whitney U Test with 0.05 level of significance using SPSS 13.0 program was used for the analysis of quantified biofilm as affected by the plant extracts. ct values was determined using qPCR delta delta ct $(\mathrm{ddCt})$ method. Kruskal-Wallis test (non-parametric ANOVA) where means between the control and experimental set-up were compared and the significance determined if the F-values was greater than the F-crit at 0.05 level of significance was used Statistical analysis of the critical threshold value was done through ANOVA (Velasco et al., 2020).

\section{RESULTS}

\section{Antibacterial Activity of Plant Extracts Against $P$. aeruginosa}

Three (3) ethanolic extracts (A. intermedia seeds, $C$. winterianus leaves, $H$. suaveolens leaves) have antibacterial activity against the clinical isolate and two ethanolic extracts (A. intermedia seeds; $C$. winterianus leaves) have antibacteria activity against the reference strain $P$. aeruginosa PNCM 1335. Sixteen (16) ethanolic extracts tested in clinical isolate while seventeen (17) extracts tested in reference strain did not exhibit antibacterial activity making them qualified for the biofilm virulence assay. Results are shown in Table 1

\section{Plant Extracts Inhibit Biofilm Formation}

In the clinical isolate, seven (7) ethnobotanical extracts namely $M$. micrantha leaves $(0.11 \mathrm{mg} / \mathrm{ml}) ; H$. suaveolens flowers $(0.78 \mathrm{mg} / \mathrm{ml}) ; H$. vulgaris leaves $(0.00 \mathrm{mg} / \mathrm{ml}) ;$ A intermedia leaves $(1.11 \mathrm{mg} / \mathrm{ml}) ; E$. indica leaves $(1.11 \mathrm{mg} / \mathrm{ml}) ; D$. esculentum $(0.78 \mathrm{mg} / \mathrm{ml})$; and Talahib $(0.67 \mathrm{mg} / \mathrm{ml})$ exhibited significant decrease in optical density (OD) values in biofilm formation compared to the negative control (without extract) with a value of $2.12 \mathrm{mg} / \mathrm{ml}$. In contrast, six (6) plant extracts not only had no effect against biofilm formation and even showed significantly higher OD values in comparison to the control. These plants are $P$. urinaria leaves $(3.56 \mathrm{mg} / \mathrm{ml}) ;$ D. philippinensis leaves $(2.88 \mathrm{mg} / \mathrm{ml}) ;$ S. alata leaves $(2.22 \mathrm{mg} / \mathrm{ml}) ; U$. lobata leaves $(2.25 \mathrm{mg} / \mathrm{ml}) ; C$. pentandra leaves $(2.33 \mathrm{mg} / \mathrm{ml})$; and Ficus sp. leaves $(2.44 \mathrm{mg} / \mathrm{ml})$, respectively. These showed no QSI activity but rather enhanced the formation of biofilm. Results are shown in Figure 1.

Twelve (12) extracts showed notable lower values in biofilm formation on the reference strain (PNCM 1335) showing QSI activity. The extracts of $M$ micrantha $(0.00 \mathrm{mg} / \mathrm{ml}) ; H$. suaveolens leaves $(0.11 \mathrm{mg} / \mathrm{ml}) ; H$. suaveolens flowers $(0.11 \mathrm{mg} / \mathrm{ml} \mathrm{H}$. vulgaris $(1.00 \mathrm{mg} / \mathrm{ml}) ;$ A. intermedia $(0.00 \mathrm{mg} / \mathrm{ml}) ; D$. esculentum $(0.33 \mathrm{mg} / \mathrm{ml}) ; S$. jamaicensis $(1.00 \mathrm{mg} / \mathrm{ml}) ; U$. lobata $(1.00 \mathrm{mg} / \mathrm{ml})$; C. pentandra $(1.00 \mathrm{mg} / \mathrm{ml}) ; E$. indica roots $(0.78 \mathrm{mg} / \mathrm{ml}) ; E$. indica leaves $(1.00$ $\mathrm{mg} / \mathrm{ml})$ and Talahib $(0.00 \mathrm{mg} / \mathrm{ml})$ showed significantly lower OD measurement than the control $(2.33 \mathrm{mg} / \mathrm{ml})$. The plant extracts, $P$. urinaria, D. philippinensis and $S$. alata significantly increased biofilm in the test isolates. Results are shown in Figure 2. 
Table 1 Antibacterial activity of plant extracts against $P$. aeruginosa clinical isolate and P. aeruginosa PNCM 1335

\begin{tabular}{|c|c|c|c|}
\hline SCIENTIFIC NAME & LOCAL NAME & CLINICAL ISOLATE & $\begin{array}{c}\text { REFERENCE STRAIN } \\
\text { PNCM } 1335\end{array}$ \\
\hline Stachytarpeta jamaicensis & Luzviminda & - & - \\
\hline Adenanthera intermedia Merr. & Kares stems & + & + \\
\hline Mikania micrantha Kunth. & Ola-ola & - & - \\
\hline Hyptis suaveolens Poir. & Ambabangot flowers & - & - \\
\hline Premna odorata Blanco & Asédaong & - & - \\
\hline Cymbopogan winterianus Jowit. & Taday & + & + \\
\hline Phyllanthus urinaria L. & Taltalikod & - & - \\
\hline Dillenia philippinensis Rolfe & Katmon & - & - \\
\hline Hydrocotyle vulgaris & Gotu kola & - & - \\
\hline Senna alata & Bensola & - & - \\
\hline Urena lobata L. & Pukot & - & - \\
\hline Ceiba pentandra & Béték & - & - \\
\hline Ficus sp. & Balete & - & - \\
\hline A. Intermedia Merr. & Kares seeds & - & - \\
\hline Eleusine indica $\mathrm{L}$. & Pag roots & - & - \\
\hline Eleusine indica L. & Pag leaves & - & - \\
\hline Diplazium esculentum & Pako-pako & - & - \\
\hline Hyptis suaveolens Poir. & Ambabangot & + & - \\
\hline \multirow[t]{3}{*}{ N/A } & Talahib & - & - \\
\hline & $\begin{array}{l}\text { Sterile distilled } \mathrm{H} 2 \mathrm{O} \text { (- } \\
\text { control) }\end{array}$ & - & - \\
\hline & Norfloxacin (+ control) & + & + \\
\hline
\end{tabular}

Note: (+) = with antibacterial activity; (-) without antibacterial activity

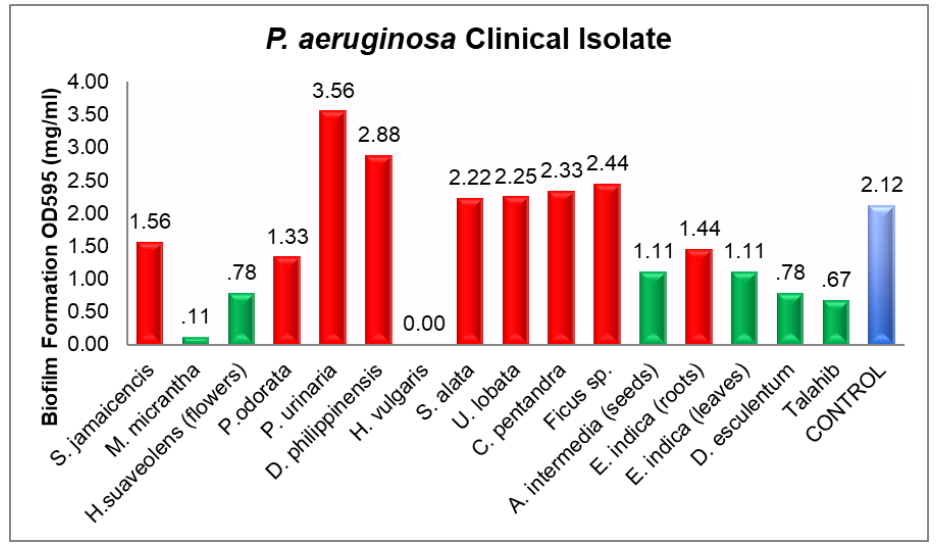

Figure 1 Biofilm formation mean optical density (OD)values in P. aeruginosa clinical isolate

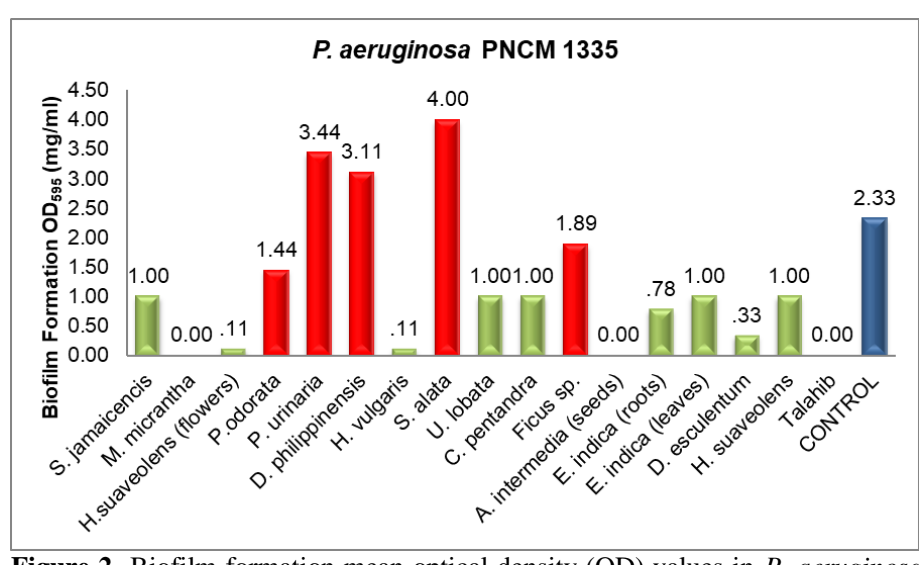

Figure 2 Biofilm formation mean optical density (OD) values in $P$. aeruginosa PNCM 1335

\section{Plant extracts downregulate las $R$}

The plant extracts with the lowest recorded OD values in the biofilm formation assay were subjected to gene expression analysis. These were M. micrantha, $H$. vulgaris, A. intermedia and Talahib.

las $R$ ct values in the clinical isolate treated with $M$. micrantha, A. intermedia and Talahib showed significant decrease in ct values validating the results in QSI biofilm quantification. Results are shown in Figure 3.

Similar to the clinical isolate, lasR ct values in the reference strain PNCM 1335 showed significant downregulation as affected by the plant extracts $(M$. micrantha with 1.87 and A. intermedia with 1.85 ) having 10.75 mean ct value. Results are shown in Figure 4. 


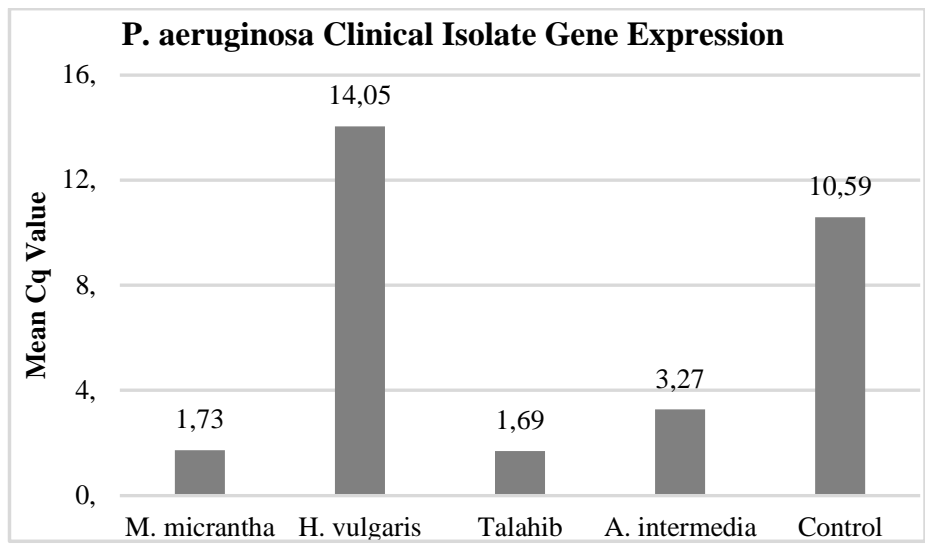

Figure 3 las $R$ expression in $P$. aeruginosa clinical isolate

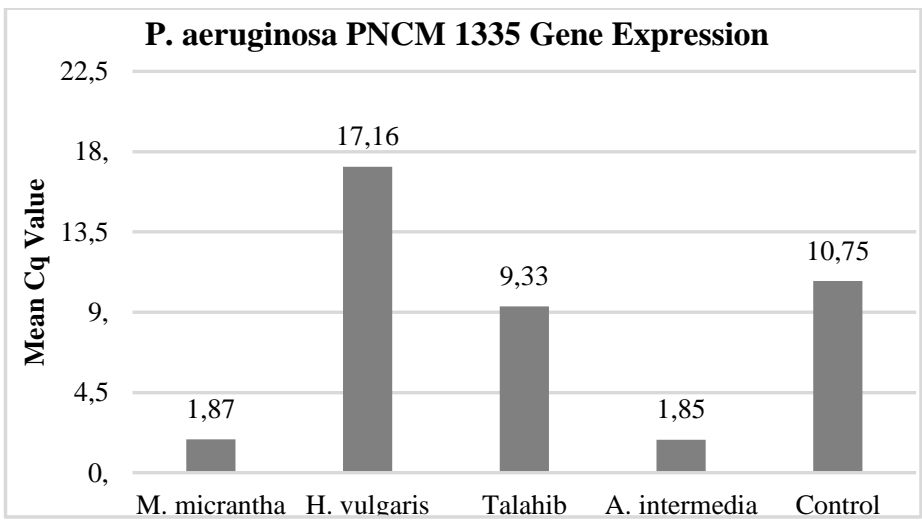

Figure 4 las $R$ expression in in P. aeruginosa PNCM 1335

\section{DISCUSSION}

QS-linked genes often control the production of virulence and gene products essential for bacterial host connections (Pirhonen et al., 1993; Parsek \& Greenberg, 2000; Pearson et al., 2000). P. aeruginosa QS system consists of a transcriptional activator, lasR or $r h l R$, and an autoinducer synthase, LasI or RhlI which manages the autoinducer PAI-1, N-(3-oxododecanoyl)-L-homoserine lactone; , RhlI on the other hand, controls the synthesis of the autoinducer PAI-2, N-butyryl-L-homoserine lactone (Pesci et al., 1999). Blocking the path to the LasR receptor may have an effect on virulence productions synthesized by other signal receptors due to their overlapping mechanics. As such in the case of $P$. aeruginosa, QS molecules C4-HSL and 3-oxo- C12-HSL, synthesized by LasI and $R h l I$, respectively, are identified by their corresponding receptors, LasR and $\mathrm{RhIR}$, when threshold quorum concentration is attained. The las and $r h l$ systems in combination, with two interconnected acyl- HSL signal-receptor pairs, 3 oxododecanoyl-HSL-LasR and butanoyl-HSL-RhIR, control as much as 353 genes that comprise around six percent of the P. aeruginosa genome (Tay \& Yew, 2013). These virulence system receptors can be blocked from synthesizing signals that mimic their complexes thereby confusing the bacterial QS, as shown when these plant extracts were applied (Livorsi et al., 2011).

las $R$ as affected by the plant extracts was significantly downregulated. This antagonistic effect may mean that the compounds in the plant extracts may have blocked the lasR pathway which control several QS virulence factors, particularly biofilm formation. As a consequence, blocking the LasR receptor may mean decrease in virulence factor production, e.g. biofilms. In other QS researches, specifically in $P$. aeruginosa biofilms, strains showing deficient production of the las signal molecule, 3O-C12-HSL, produced significantly reduced biofilms without their typical three- dimensional structure (Davies et al., 1998), confirming that the las QS system is critical in biofilm formation (De Kievit et al., 2001). LasR coordinates pathogenicity in P. aeruginosa (Adonizio et al., 2008) and activates virulence genes lasB, lasA, apr, and toxA (Gambello et al., 1993;(Pearson et al.,1997;). Therefore, if QSI compounds can block las expression, then all of the other QS-linked genes would be regulated as well, especially those involved in biofilm formation (De Kievit et al., 2001).

It can be observed that the plant extracts showed more antivirulence activity in biofilm formation in the reference strain $P$. aeruginosa PNCM 1335 than the clinical isolate. Mutations in lasR have been reported from clinical isolates of $P$. aeruginosa in cystic fibrosis patients (Hoffman et al., 2009) suggesting more possible complications in controlling its virulence system compared to the wildtype $P$. aeruginosa in which additional required autoinducer is normally provided by the las system (Papenfort \& Bassler, 2016).

Although no confirmation was done, it is hypothesized that the plant extract $H$. vulgaris downregulates another gene/s involved in biofilm formation, hence, its slightly upregulated expression. P. aeruginosa, possess numerous virulence systems aside from las, which in turn, could have been the one affected by the plant extract. These systems are $r h l, q s c$ and pqs (Gilbert et al., 2009; Chugani et al., 2001; Pesci et al., 1999; Dubern \& Diggle, 2008; Tay \& Yew, 2013) Possible targeting of these other systems by the plant extract might have occurred by blocking their receptors. QS in P. aeruginosa consists of an intricately organized hierarchical system, where substantial communications between pathways often lead to an organization of a notable number of genes (Wilder $e t$ al., 2011). As such, $H$. vulgaris may have affected other virulence factors such as pyocyanin production, DNAse and swarming motility. This result may also mean that other bacterial pathogens in which QS is controlled by lasR may benefit from the potential antagonistic or inhibitory effect of the plant extracts.

The plants that showed QSI activities are known to possess phytochemicals with known QSI activities such as phenols, tannins flavonoids, alkaloids and other secondary metabolites such as saponins (da Gama et al., 2014). It has been found that compounds from plants have already proven promising candidates for inhibiting QSI (Adonizio et al., 2008; Pawar \& Arumugan, 2011; Tan et al., 2014; Zhou et al., 2013; Husain et al., 2013).

Understanding QS gene systems crucial for virulence factors will present better insights of the connected genetic and phenotypic aspects, particularly biofilm development, and this information may ultimately pave the discovery of novel approaches for preventing and controlling complex and resistant biofilms. Since the discovery of QSI, plants have been a basis of medicines and presently continues to contribute significantly to pharmaceutical development (Cragg et al., 1997 as cited by Adonizio et al., 2006) and ironically, only around 5-15\% of the higher plants have been scientifcally explored for their bioactive molecules (Pieters \& Vlietinck, 2005). Likewise, research on the QSI activities of herbal plants is limited and it is highly probable that with in-depth studies, antimicrobial efficiency mediated by QS control will be thoroughly deliberated (Adonizio $e t$ al., 2008). The ethnobotanical extracts found to have QSI activity against a human pathogen multi-drug resistant $P$. aeruginosa can be one of the possible means of treating infections and alleviating the emerging antibiotic-resistance of many bacterial species of today. In $P$. aeruginosa, a switch to the biofilm development is connected to increased antibacterial resistance and thereby creates a distinctly more severe infection (Adonizio et al., 2008). Hence, it is now becoming more crucial to discover QSI compounds to control pathogenicity. Strategies and approaches designed to block biofilm formation in clinical and industrial cases is currently the target of researches on drug development. The confirmation of QSI of these plants is one of these strategies. The reduction of las $R$ expression and its effect on biofilm formation provide some understanding on how these can be used in the future to combat $P$. aeruginosa, a multi-drug resistant (MDR) human pathogen, and other bacterial infections.

\section{CONCLUSION}

The ethnobotanical extracts of the Ilongot-Eǵongot community showed antibacterial as well as QSI activity through inhibition of the biofilm formation in $P$. aeruginosa which was molecularly confirmed through gene expression analysis of lasR. This indicates the prospects of these ethnobotanicals for therapeutic approach to control bacterial virulence without developing resistance. It is recommended for future researches to test the extracts' QSI activity against other the $P$. aeruginosa virulence system $r h l$ and analyze its coregulation with the other QS systems.

Acknowledgement: The authors dedicate this work to the Ilongot-Egongot community of Bayanihan, Maria Aurora, Aurora, Philippines and Castaneda, Nueva Vizcaya, Philippines. The authors would also like to acknowledge the following for the use of their laboratories: Molecular Laboratory of the College of Veterinary Science and Medicine, Central Luzon State University; Biosafety and Environment Laboratory and the Reproductive Biotechnology and Physiology Laboratory of the Philippine Carabao Center, National Headquarters and Gene Pool; Department of Biological Sciences, Central Luzon State University, all located at the Science City of Munoz, Nueva Ecija, Philippines, and the Biological Sciences Department, De La Salle University-Dasmarinas, Cavite, Philippines.

\section{Compliance with Ethical Standards}

Funding: This study received no funding from any institutions or agencies. Conflict of Interest: The authors declare no conflict of interest.

Ethical Approval: This article does not contain any studies with human participants or animals performed by any of the authors.

\section{REFERENCES}

Adonizio, A.L., 2008. Anti-Quorum Sensing Agents from South Florida Medicinal Plants and their Attenuation of Pseudomonas aeruginosa Pathogenicity. FIU Electronic Theses and Dissertations. 
Adonizio, A., Kong, K.F., Mathee, K. 2008. Inhibition of Quorum Sensingcontrolled Virulence Factor Production in Pseudomonas aeruginosa by South Florida Plant Extracts. Antimicrobial Agents and Chemotherapy, 52(1):198-203. https://doi.org/10.1128/AAC.00612-07

Adonizio, A.L., Downum, K., Bennett, B.C., Mathee, K. 2006. Anti-quorum Sensing Activity of Medicinal Plants in Southern Florida. J Ethnopharma 105(3):427-435. https://doi.org/10.1016/j.jep.2005.11.025

Balberona, A.N., Noveno, J.J., Angeles, M.G.B., Santos, R.I., Cachin, E. 2018. Ethnomedicinal Plants Utilized by the Ilongot-Egongot Community of Bayanihan, Maria Aurora, Aurora, Philippines. Intl J Agri Tech 14(2):145-159.

Bauer, W.D., Mathesius, U. 2004. Plant Responses to Bacterial Quorum Sensing Signals. Current Opinion in Plant Biology 7:429-433. https://doi.org/10.1016/j.pbi.2004.05.008

Chugani, S.A., Whiteley, M., Lee, K.M., D'Argenio, D., Manoil, C., Greenberg, E.P. 2001. QscR, A Modulator of Quorum-sensing Signal Synthesis and Virulence in Pseudomonas aeruginosa. Proc Natl Aca Sci 98(5):2752-2757. www.pnas.org/cgi/doi:10.1073/pnas.051624298

Cos, P., Vlietinck, A.J., Berghe, D.V., Maes, L. 2006. Anti-infective Potential of Natural Products: How to Develop a Stronger In Vitro 'Proof-of-Concept'. J Ethnopharma 106(3):290-302. https://doi.org/10.1016/j.jep.2006.04.003

Cragg, G.M., Newman, D.J., Snader, K.M. 1997. Natural Products in Drug Discovery and Development. J Nat Prod 60(1):52-60. https://doi.org/10.1021/np9604893

Da Gama, B.A., Plougerne, E., Pereira, R.C. 2014. The Antifouling Defence Mechanisms of Marine Macroalgae. In Adv Bot Res, Acad Pr 71:413-440. http://dx.doi.org/10.1016/B978-0-12-408062-1.00014-7

Davies, D.G., Parsek, M.R., Pearson, J.P., Iglewski, B.H., Costerton, J.W., Greenberg, E.P. 1998. The Involvement of Cell-to-cell Signals in the Development of a Bacterial Biofilm. Sci 280 (5361):295-8 https://doi.org/10.1126/science.280.5361.295

De Kievit, T.R., Gillis, R., Marx, S., Brown, C., Iglewski, B.H. 2001. Quorumsensing Genes in Pseudomonas aeruginosa Biofilms: Their Role and Expression $\begin{array}{llll}\text { Patterns. Appl } & \text { Envi } & \text { Micro } & \end{array}$ https://doi.org/10.1128/AEM.67.4.1865-1873.2001

Djordjevic, D., Wiedmann, M., McLandsborough, L.A. 2002. Microtiter Plate Assay for Assessment of Listeria monocytogenes Biofilm Formation. Appl Envi Micro 68(6):2950-2958. https://doi.org/10.1128/AEM.68.6.2950-2958.2002 Driscoll, J.A., Brody, S.L., Kollef, M.H. 2007. The Epidemiology, Pathogenesis and Treatment of Pseudomonas aeruginosa Infections. Drugs 67(3):351-368. https://doi.org/10.2165/00003495-200767030-00003

Dubern, J.F., Diggle, S.P. 2008. Quorum Sensing by 2-alkyl-4-quinolones in Pseudomonas aeruginosa and other Bacterial Species. Mol BioSyst 4:882-888. https://doi.org/10.1039/b803796p

Fernando, S.I.D., Judan Cruz, K.G. 2020. Ethnobotanical biosynthesis of gold nanoparticles and its downregulation of Quorum Sensing-linked AhyR gene in Aeromonas hydrophila. Springer Nature Applied Sciences 2:570 https://doi.org/10.1007/s42452-020-2368-1

Gambello, M.J., Kaye, S., Iglewski, B.H. 1993. LasR of Pseudomona aeruginosa is a Transcriptional Activator of the Alkaline Protease Gene (apr) and an Enhancer of Exotoxin A Expression. Inf Immun 61(4):1180-1184 https://doi.org/10.0000/iai.asm.org/iai/61/4/1180

Gilbert, K.B., Kim, T.H., Gupta, R., Greenberg, E.P., Schuster, M. 2009. Global Position Analysis of the Pseudomonas aeruginosa Quorum-Sensing Transcription factor lasR. Mol Micro 73:1072-1085. https://doi.org/10.1111/j.1365-2958.2009.06832.x

Handa, H. 2008. Linear Plasmids in Plant Mitochondria: Peaceful Coexistences or Malicious Invasions? Mitoch 8(1):15-25 https://doi.org/10.1016/j.mito.2007.10.002

Hentzer, M., Givskov, M. 2003. Pharmacological Inhibition of Quorum Sensing for the Investigation. J Clin Inv 112(9):130. https://doi.org/10.1172/JCI20074 Hentzer, M., Wu, H., Andersen, J.B., Riedel, K., Rasmussen, T.B., Bagge, N., Kumar, N., Schembri, M.A., Song, Z., Kristoffersen, P., Manefield, M. Costerton, J.W., Molin, S., Eberl, L., Steinberg, P., Kjelleberg, S., Hoiby, N., Givskov, M. 2003. Attenuation of Pseudomonas aeruginosa Virulence by Quorum Sensing Inhibitors. EMBO Journ 22(15):3803-3815. https://doi.org/10.1093/emboj/cdg366

Hoffman, K., Zage, D., Nita-Rotaru, C. 2009. A Survey of Attack and Defense Techniques for Reputation Systems. ACM Computing Surveys (CSUR) 42(1):1 https://doi.org/10.1145/1592451.1592452

Husain, F.M., Ahmad, I., Asif, M., Tahseen, Q. 2013. Influence of Clove Oil on Certain Quorum-Sensing-Regulated Functions and Biofilm of Pseudomonas aeruginosa and Aeromonas hydrophila. J Biosci 38(5):835-844. https://doi.org/10.1007/s12038-013-9385-9

Illumina, INC. 2010. Absolute Quantification of Gene Expression using SYBR Green in the EcoTM real-time PCR System. Retrieved: August 10, 2017.

Judan Cruz, K.G., Gatchalian, J.J., Jacinto, W.R. 2018. Philippine Ethnobotanicals Inhibit Quorum Sensing-Controlled Biofilm Foormation In Pseudomonas aeruginosa. International J Biol, Pharm All Sci 7(4):527-537.
Kalia, V.C., Rani, A., Lal, S., Cheema, S., Raut, C.P. 2007. Combing Databases Reveals Potential Antibiotic Producers. Exp Op Dr Disc 2(2):211-224 https://doi.org/10.1517/17460441.2.2.211

Livorsi, D.J., Stenehjem, E., Stephens, D.S. 2011. Virulence Factors of Gramnegative Bacteria in Sepsis with a Focus on Neisseria meningitidis. In SepsisPro- Inflammatory and Anti-Inflammatory Responses, Karger Publishers 17:31 47. https://doi.org/10.1159/000324008

O’Loughlin, C.T., Miller, L.C., Siryaporn, A., Drescher, K., Semmelhack, M.F., Bassler, B.L. 2013. A Quorum-sensing Inhibitor Blocks Pseudomonas aeruginosa Virulence and Biofilm Formation. Proc Natl Aca Sci 110(44):1798117986. www.pnas.org/cgi/doi/10.1073/pnas.1316981110

Papenfort, K., Bassler, B.L. 2016. Quorum Sensing Signal-response Systems in Gram- negative Bacteria. Nat Rev Micro 14(9):576-588 https://doi.org/10.1038/nrmicro.2016.89

Parsek, M.R., Greenberg, E.P. 2000. Acyl-homoserine Lactone Quorum Sensing in Gram-negative Bacteria: A Signaling Mechanism Involved in Associations with Higher Organisms. Proc Natl Aca Sci 97(16):8789-8793. https://doi.org/10.1073/pnas.97.16.8789

Pawar, N.K., Armugan, N. 2011. Leaf Extract of Centratherum punctatum Exhibits Antimicrobial, Antioxidant and Antiproliferative Properties. Asn J Pharma Clin Res 4(3):71-76.

Pearson, J.P., Pesci, E.C., Iglewski, B.H. 1997. Roles of Pseudomonas aeruginosa las and rhl Quorum-sensing Systems in Control of Elastase and Rhamnolipid Biosynthesis Genes. J Bacte, 179(18):5756-5767. https://doi.org/10.1128/jb.179.18.5756-5767.1997

Pesci, E.C., Milbank, J.B., Pearson, J.P., McKnight, S., Kende, A.S., Greenberg, E.P., Iglewski, B.H. 1999. Quinolone Signaling in The Cell-to-cell Communication System of Pseudomonas aeruginosa. Proc Natl Aca Sci 96(20):11229-11234. https://doi.org/10.1073/pnas.96.20.11229

Pieters, L., Vlietinck, A.J. 2005. Bioguided Isolation of Pharmacologically Active Plant Components, Still a Valuable Strategy for the Finding of New Lead Compounds?

https://doi.org/10.1016/j.jep.2005.05.029

Pirhonen, M., Flego, D., Heikinheimo, R., Palva, E.T. 1993. A Small Diffusible Signal Molecule is Responsible for the Global Control of Virulence and Exoenzyme Production in the Plant Pathogen Erwinia carotovora. EMBO 12(6):2467-2476.

2075.1993.tb05901.x

Rasmussen, T.B., Bjarnsholt, T., Skindersoe, M.E., Hentzer, M., Kristoffersen P., Te, M.K., Nielsen, J., Eberl, L., Givskov, M. 2005. Screening for Quorumsensing Inhibitors (QSI) by Use of a Novel Genetic System, the QSI Selector. J Bacte, 187(5):1799-1814. https://doi.org/10.1128/JB.187.5.1799-1814.2005

RASMUSSEN, T.B., GIVSKOV, M. 2006. Quorum Sensing Inhibitors: A Bargain of Effects. Micro, 152(4):895-904. https://doi.org/10.1099/mic.0.28601

Rezai, A., Oyong, G.G., Borja, V.B., Inoue, M., Abe, T., Tamamura, R., Nagatsuka, H., Setsu, K., Buery, R.R. 2011. Molecular Screening of Anti-quorum Sensing Capability of Salvadora persica on Enterococcus faecalis. J Hard Tis Biol, 20(2):115-124

https://doi.org/10.2485/jhtb.20.115

Rutherford, S.T., Bassler, B.L. 2012. Bacterial Quorum Sensing: Its Role in Virulence and Possibilities for Its Control. Cold Spr Har Pers Med 2(11):1-26. https://doi.org/10.1101/cshperspect.a012427

Sia, I.C., Sur, A.L.D., Co, L., Naynes, R.S., Bernardo, A.M.A. 2002 Ethnopharmacological Study of The Philippine Ethnolinguistic Groups: The Bugkalot People of Talbec, Dupax Del Sur, Nueva Vizcaya. Complementary and Traditional Medicine Study Group National Institutes of Health University of the Philippines Manila.

Srisawat, S. 2007. Effect of some Thai Medicinal Plant Extracts on Antibacteria Activity of Periodontopathic Bacteria and Their Anti-inflammatory Activity and Toxicity to Gingival Connective Tissue Fibroblast (Doctoral dissertation, Prince of Songkla University).

Tan, M.W., Rahme, L.G., Sternberg, J.A., Tompkins, R.G., Ausubel, F.M. 1999 Pseudomonas aeruginosa Killing of Caenorhabditis elegans used to Identify $P$. aeruginosa Virulence Factors. Proc Natl Aca Sci 96(5):2408-2413 https://doi.org/10.1073/pnas.96.5.2408

Tan, L.Y., Yin, W.F., Chan, K.G. 2013. Piper nigrum, Piper betle and Gnetum gnemon-Natural Food Source with Anti-Quorum Sensing Properties. Sens 13(3):3975-3985. https://doi.org/10.3390/s130303975

Tay, S.B., Yew, W.S. 2013. Development of Quorum-Based Anti-Virulence Therapeutics Targeting Gram-Negative Bacterial Pathogens. Intl J Mol Sci 14:16570-16599. https://doi.org/10.3390/ijms140816570

Velasco, A.T. Jr, Fernando, S.I.D., Judan Cruz, K.G. 2020. lasR/rhlR Expression Linked to Quorum Sensing-Mediated Biofilm Formation in Pseudomonas aeruginosa Using Gold Nanoparticles Synthesized with Ethnobotanical Extracts. BioNanoScience (2020)

https://doi.org/10.1007/s12668-020-00757-7

Wada, M., Lkhagvadorj, E., Wang, C., Chiba, Y., Nagata, S., Shimizu, T. Yamashiro, Y., Asahara, T., Nomoto, K. 2009. Quantitative Reverse Transcription-PCR Assay for the Rapid Detection of Methicillin-resistant 
Staphylococcus aureus. J Appl Micro, 108(3):779-788. https://doi.org/10.1111/j.1365-2672.2009.04476.x

Wilder, C.N., Diggle, S.P., Schuster, M. 2011. Cooperation and Cheating in Pseudomonas aeruginosa: The Roles of the las, rhl and pqs Quorum-sensing Systems. ISME J 5:1332-1343. https://doi.org/10.1038/ismej.2011.13

Zhou, L., Zheng, H., Tang, Y., Yu, W., Gong, Q. 2013. Eugenol Inhibits Quorum Sensing at Sub-Inhibitory Concentrations. Biotech Lett 35(4):631-637. https://doi.org/10.1007/s10529-012-1126-X 